\title{
7. \\ MOGUĆNOSTI KORIŠTENJA \\ TRADICIJSKE KULTURE U \\ RURALNOM TURIZMU I ODRŽIVOM \\ RAZVOJU RAVNIH KOTARA
}

\section{Marijeta Rajković Iveta}

UDK: 304.3:338.48(497.5 Ravni kotari)

Sažetak: Na području gornjih Ravnih kotara provedena su etnološka terenska istraživanja (2005. i 2006. godine) na osnovi kojih je nastao zbornik radova Zapisi iz gornjih Ravnih kotara, etnološki, povijesni i muzeološki prilozi o Islamu Latinskom, Islamu Grčkom, Kašiću i Podgradini. U radu se prikazuje kako se rezultati tih istraživanja mogu koristiti u revitalizaciji ovoga područja kroz oblike ruralnog turizma, osnivanjem ekomuzeja s epicentrom u Kuli Stojana Jankovića, radionicama za senzibiliziranje lokalnog stanovništva i njegovu samozapošljavanju. Daju se smjernice za nastavak etnoloških i kulturnoantroploških istraživanja.

Ključne riječi: Ravni kotari, ruralni turizam, ekomuzej, održivi razvoj, Kula Stojana Jankovića

\footnotetext{
odine 2005. prof. dr. sc. Drago Roksandić zamolio je prof. dr. sc. Milanu Černelić da fe sa suradnicama s Odsjeka za etnologiju i kulturnu antropologiju Filozofskog fakulteta Sveučilišta u Zagrebu, među kojima sam u to vrijeme bila i ja, priključi interdisciplinarnom znanstvenom istraživanju Ravnih kotara. Jedan od naših doprinosa realizaciji navedenoga projekta trebao je biti istražiti tradicijsku i suvremenu kulturu u etnokonfesionalno miješanom području sela Islama Latinskog i Grčkog, sa svrhom vrednovanja kulturnoga nasljeđa ovoga područja. Budući da je "sudbina” Kule Jankovića uvijek bila nerazlučiva od svoga užeg i šireg okoliša, interdisciplinarnim i komparativnim studijama željeli smo doprinijeti obnavljanju međuljudskog povjerenja na ovim razmeđima, uvelike traumatiziranu ratnim pustošenjima. Naš prvi korak u tim nastojanjima bio je organizacija etnografskog terenskog istraživanja, po mnogočemu specifičnog s obzirom na poratne okolnosti. U hrvatskoj etnologiji tijekom i nakon Domovinskog rata nastali su brojni članci i knjige iz područja ratne etnologije, međutim u okviru tih projekata istraživalo se isključivo ratno iskustvo i/ili tradicijska baština stanovništva hrvatske narodnosti (usp. Rihtman-Auguštin i Muraj 1998:115-124). Naše istraživanje bilo je prvo poratno etnološko istraživanje u mješovitoj etnokonfesionalnoj sredini. Realizacija takvog pothvata u takvim okolnostima nije
} 
bila jednostavna. Osim same pripreme terena i na konkretnom empirijskom istraživanju susreli smo se s mnogim izazovima poput zatvorenosti zajednice te mnogim istraživačkim i etičkim dilemama (usp. Černelić i Rajković Iveta 2010:10-12).

Istraživanje je provedeno $\mathrm{i}$ to $\mathrm{u}$ obliku terenske nastave u okviru dodiplomskog studija etnologije i kulturne antropologije. U njemu je sudjelovalo šestero studenata. Istraživanja su izvedena tijekom dva navrata 2005. godine i 2006. godine u trajanju od po sedam dana na području sela: Islam Latinski (zaselci: Grgurice, Rupalj), Islam Grčki (zaseok Kožul), Kašić, Smilčić i Podgradina. Rezultat istraživanja je zbornik radova Zapisi iz gornjih Ravnih kotara, etnološki, povijesni i muzeološki prilozi o Islamu Latinskom, Islamu Grčkom, Kašiću i Podgradini (2010), urednica Milane Černelić i Marijete Rajković Iveta.

Svaki je student prema vlastitoj želji odabrao i istraživao jednu od ponuđenih tema i, uz mentorstvo voditeljica terenske nastave, kasnije urednica zbornika, proveo istraživanje. U zborniku su navođeni autentični iskazi ljudi različitih dobi, oba roda iz navedenih sela. Autori pojedinih priloga nastojali su predočiti življeno iskustvo lokalnog stanovništva i kontekstualizirati pojave iz perspektive naših sugovornika. Koristili smo metode intervjua, razgovarali smo sa 64 stanovnika navedenih sela, snimili oko 250 sati razgovora, fotografirali i skenirali 320 fotografija i osobnih dokumenata. Istraživači, studenti četvrte godine etnologije i kulturne antropologije, bili su: Valentina Baćac (istraživala je tradicijsku prehranu), Ivan Galić (godišnje običaje), Sanja Galović (narodnu medicina i higijenu te vjerovanja u nadnaravna bića), Mura Kokotović (maslinarstvo, lov i vodenice za mljevenje žita), Sanja Lončar (ruralno graditeljstvo i kulturu stanovanja) i Tamara Nikolić (opskrbu vodom, navodnjavanje i zemljoradnju). Na drugom istraživanju studentima etnologije pridružilo se dvoje studenata dodiplomskog studija povijesti Martina Krivić, studentica etnologije i povijesti, te Stipe Kljaić, student jednopredmetne povijesti. Oni su istraživali toponimiju i patronimiju ovoga kraja kombinirajući metodu usmene povijesti s katastarskim podacima iz 17. stoljeća.

Projekt je bio tako osmišljen da se provođenjem terenskih istraživanja nastojalo poticati mlade istraživače, studente, uglavnom dvopredmetnih studija, na timski rad i na interdisciplinarnu suradnju. Studenti su na konkretnom istraživačkom zadatku uspješno prošli sve faze istraživačkog rada. Rad na zborniku uvelike je premašio studentske obveze, a radni entuzijazam ove grupe studenata, ujedno i autora priloga, doveo je do iznimnih rezultata na temelju kojih su oni nagrađeni studentskom nagradom Franjo Marković Filozofskoga fakulteta u Zagrebu za 2006./07. akademsku godinu.

Spomenula bih da se je već sam naš terenski rad, odnosno komunikacija s članovima lokalne zajednice, pokazao iznimno produktivnim u osvješćivanju kulturnopovijesnih vrijednosti i potencijala ovoga kraja. Našim propitivanjima i fotografiranjima materijalne kulture lokalno stanovništvo uočilo je važnost tih predmeta i postalo svjesno da ih treba sačuvati.

Etnološki, povijesni i muzeološki prilozi o Islamu Latinskom, Islamu Grčkom, Kašiću i Podgradini prikazani u navedenom zborniku radova idu u prilog da se na temelju spoznaja o vlastitoj prošlosti i tradicijskom nasljeđu može doprinijeti revitalizaciji ovoga područja osnivanjem (eko)zavičajnoga muzeja i njegovim uklapanjem u ponudu ruralnog i kulturnoga turizma. Zbornik je namijenjen širokom krugu čitatelja i korisnika: od znanstvenika, studenata, gospodarstvenika, kulturnih djelatnika do stanovnika istraživanoga područja, cijele ove regije. Jedan od njegovih ciljeva je i popularizacija znanstvenih spoznaja o Ravnim kotarima i njihova primjenjivost u gospodarske svrhe. U svakom slučaju, istraživanja su usmjerena $\mathrm{k}$ teorijskom i praktičnom propitivanju međuodnosa kulture i održivog raz- 
voja. Između ostaloga, željeli smo da se dobivene spoznaje mogu koristiti i pri organiziranju radionica za senzibiliziranje lokalne zajednice prema baštini, posebno u svrhu utvrđivanja lokalnih, izvornih ekoproizvoda i obogaćivanja kulturno-turističke ponude.

U nastavku teksta predstavit ću svaku istraživanu temu i ukazati na mogućnosti korištenja tradicijske kulture u ruralnom turizmu i održivom razvoju. Provedena etnološka istraživanja, odnosno konkretni segmenti tradicijske kulture istraživanih sela, postavljeni u konceptualno širi kontekst, mogu formirati korpus održivih aktivnosti i akcija kao konstruktivni prilog muzeološkoj teoriji i praksi za osnivanje ekomuzeja s epicentrom u Kuli Stojana Jankovića, o čemu smo kolega muzeolog i etnolog Darko Babić i ja 2009. godine napisali koautorski rad pod naslovom "Prilog za razvoj ekomuzeja u Ravnim kotarima" objavljen u časopisu Studia ethnologica Croatica.

Dakle, osim temeljnih spoznaja i obogaćivanja etnoloških saznanja o ovome do tada slabo istraživanom prostoru, prikupljanje etnoloških i kulturnoantroploških podataka mogu biti polazište za osnivanje ekomuzeja u Kuli Stojana Jankovića u Islamu Grčkom, ideji pokrenutoj u sklopu projekta pod radnim naslovom "Mostovi". Projekt "Mostovi" pokrenut je 2004. godine na Filozofskom fakultetu u Zagrebu pod vodstvom dr. sc. Drage Roksandića, red. prof. s Odsjeka za povijest. Projekt je bio multidisciplinaran, a glavni nositelji su istraživači s Odsjeka za povijest, Odsjeka za etnologiju i kulturnu antropologiju i Katedre za muzeologiju (svi s Filozofskog fakulteta Sveučilišta u Zagrebu) te Instituta "Ruđer Bošković" i Centra za mirovne studije. ${ }^{1}$

Važno je napomenuti da prijedlozi akcija budućeg ekomuzeja i iznesene ideje predstavljaju više natuknice za razmišljanje i poziv na dodatno istraživanje i definiranje mogućih aktivnosti negoli konačne oblike njihove primjene, između ostalog i zato što se temelje isključivo na prvim etnološkim istraživanjima. Bez obzira na manjkavosti takvog parcijalnog pristupa, kolega Babić i ja u navedenom radu smatramo da je vrijedno i bitno od samog početka naznačiti potencijale i mogućnosti koje nudi prostor na kojemu su do sada obavljena istraživanja. Smatramo da će se na taj način potaknuti nove ideje i doprinijeti konstruktivnoj raspravi o njima, ali isto tako idejno demonstrirati primjenjivost znanstvenih istraživanja u praksi (usp. Babić i Rajković Iveta 2009).

Boravkom na terenu u istraživanim selima zatečeno je nekoliko stambenih kompleksa (posebice u zaselku Kožul u Kašiću) građenih na tradicijski način. Osnovni građevni materijal na ovom području bio je kamen, a upotrebljavao se i danas poznati benkovački kamen. Alati za obradu kamena, između ostalog, bili su špicalj i macun, kamene ploče nabavljale su se u Pridragi i u Kašiću. Kao građevni materijal koristila se pržina (žuta zemlja), pijesak koji se miješao s krečom (klakom, vapnom) i vodom te je tako nastajala malta (vezivni materijal, preteča betona), gnjila (zemlja ilovača), bila zemlja. Zidalo se pomoću nekoliko tehnika, na primjer tehnikom suhozida is maltom. Pokrivanje objekata vršilo se ševarom (raži), kupom, ternitom. Drvo je također imalo široku primjenu u stolariji, ali i interijeru. Osim stambenih objekata u ovom kraju postoje i karakteristični gospodarski objekti i prostori u okućnici: košara, kotarina (spremišta za kukuruz u klipu), guvno (prostor za vršenje žita), krušna peć izvan kuće, sušnice, pecare, spremišta za vino, ulje, krumpir. Tijekom istraživanja uočene su kronološke promjene u tehnikama gradnje tijekom 20. stoljeća te različitost lokalnih naziva za pojedine lokalitete (s obzirom na etničku i konfesionalnu pripadnost stanovništva) (usp. Lončar 2010:73-176).

Vidi: www.ffzg.hr/mostovi (pristup 10. 7. 2014.). 
Budući da je veći broj kuća (pa tako i starih kuća) i gospodarskih objekata uništen tijekom Domovinskog rata, jedna od važnih zadaća ekomuzeja morala bi biti pomoć lokalnom stanovništvu pri njihovoj obnovi. Pri tome podrazumijevamo zalaganje, protežiranje i podršku gradnje na tradicionalan, lokalnom području svojstven način. Ne znači to potpuno odbacivanje suvremenih materijala i tehnika, no svakako uvijek podrazumijeva i obnovu i gradnju u harmoniji s krajolikom u kojem se nalaze. Razvoj i tradicija nisu u suprotnosti, kako se još uvijek ponekad misli, a jedan od snažnih argumenata u ovom pravcu jesu i suvremeni trendovi u turizmu gdje se za smještajne kapaciteta za potrebe boravka posjetitelja na seoskim gospodarstvima i domaćinstvima traže autentični oblici. Da ne dođe do nepotrebnog nesporazuma, smatramo samorazumljivim da ekomuzej nije i ne smije biti primarno okrenut interesima i potrebama turista, već upravo lokalnoj zajednici, no kako je njegova uloga da se brine o razvoju (dakle i komponentni razvoja turizma), upravo zbog toga je njegova savjetodavna uloga u tom području izuzetno bitna (usp. Babić, Rajković Iveta 2009:318). U ovom pravcu poželjno je i organiziranje radionica koje bi demonstrirale razne tehnike obrade kamena, obrade drveta ili tehnike pokrivanja stambenih prostora - kako za lokalno stanovništvo, tako i za moguće i dobrodošle goste i posjetitelje koji bi mogli boraviti u npr. objektima koji se osvjetljavaju s luči ili voštanim svijećama. Od elemenata interijera koji su se koristili u kućama zanimljivi su i: katriga (stolica), bančić (drvena klupica za sjedenje s dvije noge), naćve (drvena posuda u kojoj se kruv misio), slamarica (preteča madraca) punjena slamom ili perušinom (listovima od kukuruza), tekstilno rukotvorstvo, primjerice: šarenice (prekrivači i pokrivači za krevet), biljci (pokrivači). Moguće bi bilo organizirati raznovrsne radionice za izradu predmeta iz tekstilnog rukotvorstva, kao i raznih upotrebnih predmeta u kućanstvu. Na primjer, na ovom području voda se mogla piti iz kaciole, kaciolice (zaimača ili šeflja), čikare (šalica), bukare (drvena posuda s ručkom od otprilike pola litre, koja se i danas može kupiti u Benkovcu na sajmu), pićuna (lončić od litru do tri litre), važića (mali lončić). U pojedinim kućanstvima moguće je organizirati i uprizoriti pranje rublja na tradicijski način - iskuhavanje u lugu (pepelu), ispiranje na izvorima, pravljenje domaćeg sapuna kuhanjem životinjskih kostiju. Ova sela imala su i bogatu komunikaciju sa susjednim zajednicama: primjerice u Lovincu su se nabavljale škrinje za miraz (koristile su se za spremanje tekstilnih predmeta prije upotrebe ormara), na benkovačkom pazaru se nabavljala većina predmeta koji su se koristili u kućanstvu (usp. Lončar 2010), tako da bi ti lokaliteti bili nezaobilazni dio itinerara.

Istraživano područje Ravnih kotara ima plodno tlo i bogato je vodom te je poljoprivreda bila primarna gospodarska grana. Stanovništvo se prije Domovinskog rata bavilo poljoprivredom za šire tržište i "na veliko", posebice Islam Grčki i Kašić, koji su puno bogatiji izvorima vode nego Islam Latinski. Iz Islama Grčkog i Kašića povrće i voće su prodavali u Zadru, Puli, Zagrebu, Lošinju, Rijeci, Crikvenici, Karlobagu, Gračacu, Titovoj Korenici i Obrovcu. No, u svim istraživanim lokalitetima sredinom 20. stoljeća bila je raširena proizvodnja kukuruza, pšenice, raži i pamuka. Od povrtnih biljaka prisutne su rajčice, paprika, grah jari, tikvice, kupus, krastavci i lubenice. Od šezdesetih godina 20. stoljeća započinje i sadnja presada u plastenicima (usp. Nikolić 2010:226-239). Pretpostavimo li ispravno da se današnja ekoproizvodnja, koja je po mnogim ekonometrijskim računicama i financijski isplativija, umnogome oslanja i na tradiciju, ekomuzej bi trebao biti promotor i pokretač takve poljoprivrede, prije svega da time pomogne lokalnom stanovništvu (usp. Babić, Rajković Iveta 2009:320). U razrađenoj pak interpretativnoj funkciji takvih oblika potencijalni posjetitelji bi mogli sudjelovati u svojevrsnom prijenosu kolektivnog iskustva, sudjelo- 
vanjem u raznim poljodjelskim poslovima prilikom pripreme zemlje za sadnju sadnica (na primjer oranje plugom na volovima ili konjima), branju plodova, žetvi žita, pravljenje $u z ̌ a d i$ i vezanje žita, vršenju žita na gumnu pomoću volova i konja. Mogli bi isto tako sudjelovati u izradi alata za poljodjelstvo kod kovača, izradi drvenih proizvoda, tkanju bisaga (torbi iz kojih se sije žito). Budući da je sastav stanovništva etnički i konfesionalno raznolik (usp. Brtan 2002:7-12), unatoč vrlo sličnom načinu obrade zemlje na istraženom području, postoje razna vjerovanja vezana za iste prakse te bi potencijalnim posjetiteljima sigurno bilo zanimljivo prezentirati i priče i vjerovanja kako poboljšati urod ljetine.

Budući da ovaj kraj obiluje i izvorima vode, važne točke interpretacije morali bi biti izvori i bunari. U prvoj polovini 20. stoljeća, kada je bunar presušio, žene su iz obližnjih izvora do kuća nosile vodu na glavi u kabama (drvene posude od 10 - 15 l). Prilikom nošenja na glavi ispod kabe stavljala se spara, kotlja ili kotuljak (jastučić napravljen od krpa). Voda se do kuće također prenašala na magarcima u burlima ili vučijama (drvene posude od cca 25 l), koje su se kupovale na pazaru ili su ih u selo donosili stanovnici Velebita (usp. Nikolić 2010:239-251). Osim prikaza ovih tradicijskih načina transporta, mogle bi se napraviti radionice za izradu tih drvenih predmeta, pa i u varijantama prilagođenim suvremenoj upotrebi u kućanstvu te ih prodavati i kao suvenire. Osim izvora, kako u ovim lokalitetima, tako i na širem prostoru Ravnih kotara, postojale su brojne vodenice, na jarugama ili manjim rječicama i mlinovi. Vodenica je bilo u Posedarju, zaseoku Kolčeg, Slivnici, Karinu, Slapu, Smilčiću, Islamu Grčkom, Ruplju, Poličniku i Kašiću. Mlinovi su bili u Smilčiću, mlin Bučnovac u Kašiću, mlin Kolčegovac na rječici Bašćici i Karešnici (ibid. 243-246). Ovi su mlinovi danas u ruševnom stanju i za potrebe ekomuzeja trebalo bi ih prije svega označiti i na odgovarajući način interpretirati, a barem jedan ili dva obnoviti i staviti u funkciju. Sigurno bi se našao i neki mlinar koji je na njima radio i koji bi s ponosom to znanje demonstrirao ili bi trebalo nekoga tom poslu (ponovno) poučiti. Praksa ekomuzeja upravo omogućava da djelatnosti koje bi svaka potpuna tradicijska situacija eliminirala potraju ili nastave živjeti jer se pojavljuje "strani" konzument, odnosno turist koji ponekad osigurava i potrebnu razinu rentabilnosti. Treba imati u vidu da ekomuzeji uglavnom ne osnivaju nešto što nije postojalo, već po potrebi argumentima prodaje (turizma) pomažu da oni koji su to radili u tradicijskim okvirima i okolnostima, u istima i nastave. Ipak, radionice ovog tipa vidimo kao poželjne prije svega zbog brzog nestajanja iskustva izrade predmeta, odnosno elemenata kako materijalne tako i nematerijalne baštine (usp. Babić, Rajković Iveta 2009:321).

Od šezdesetih godina 20. stoljeća na istraživanom području bilježi se masovnija sadnja maslina zbog visoke cijene maslinova ulja na tržištu. Ranije, u prvoj polovini 20. stoljeća, nisu se kupovale sadnice, već se od stare masline ili staroga panja odcjepljivala palica ili odlipak. Autohtona sorta istraživanog područja je orkula. Poslovi uključeni oko maslina su: okopavanje motikom, podrezivanje grana škarama, gnojenje, zalijevanje vodom, berba maslina krajem listopada. Nakon toga slijedi prerada maslina i proizvodnja maslinova ulja (usp. Kokotović 2010:177-210). Osim informiranja i pomoći stanovništvu u svim ovim poslovima (uključujući i plasman na tržište) od strane ekomuzeja, njegove aktivnosti podrazumijevale bi i organizaciju sudjelovanja posjetitelja u svim gore navedenim poslovima pa čak i u danas popularnom obliku programa aktivnosti namijenjenih poboljšanju timske učinkovitosti u okviru tvrtki (team building). Maslinovo ulje koje su djelomično i sami proizveli, kao oblik stvarnog doživljajnog iskustva, činio bi jedinstvenu ponudu i dodatni izvor prihoda lokalnim stanovnicima (usp. Babić, Rajković Iveta 2009:321). Osim prerade 
maslina kod kuće, postojale su i uljare u koje su stanovnici Ravnih kotara vozili svoje masline tijekom 20. stoljeća, a koje bi u koncepciji ekomuzeja svakako bile dio proširenog itinerara: Zadar, Sukošan, Bibinje, Zaton, Šibenik, Vodice, Pirovac, Nadin, Kožul, Benkovac i Pašman. Maslinovo se ulje ponajviše koristilo za potrebe obitelji u prehrani te za uljepšavanje (na primjer za sjaj kose) (usp. Kokotović 2010:177-210). Dio ulja bi se mogao pakirati u ambalažu s tradicijskom simbolikom (razni oblici pakovanja od stakla, keramike, male kamenice) čija bi se izrada također mogla prezentirati u radionicama za izradu takve ambalaže. Osim ulja mogli bi se izrađivati i razni proizvodi povezani s uljem (na primjer sapuni). Prijedlog neizravno implicira još jednu moguću ulogu ekomuzeja u razvoju dotičnog područja, kao potencijalnog ishodišta inovacija i kreativne industrije temeljenog na osnovi kvalitetno izbalansiranog spoja tradicionalnog i suvremenog (usp. Babić, Rajković Iveta 2009:321).

Osim navedenih tema istraživali smo i lov na divlje životinje. On je na ovom području u širem smislu obuhvaćao lov unutar organiziranih lovačkih društava i krivolov (pomoću ošcalžice, kamene ploče, metalnih gvožda). Divlje životinje koje obitavaju na ovom području jesu zec, čagalj, jazavac, lisica, divlje svinje te brojne ptice poput bena, golubova, fazana, jarebica, prepelica, trčki. U istraženim lokalitetima danas je razvijen lovni turizam, ponajviše dolaze lovci iz Italije na pernatu divljač i na dresure pasa. Posebnost ovog područja je postojanje zmijara, zmijolovaca, ljudi koji su hvatali zmije, ponajviše poskoke, ali i žabe, kornjače i guštere zelembaće i prodavali ih na Bokanjcu (usp. Kokotović 2010:211-222). Ekomuzej bi mogao biti centar i upravitelj lovačkih aktivnosti, dok bi zmijarstvo moglo biti prezentirano interaktivnom multimedijom ili, ukoliko bi se pokazao interes, i kao oblik specifične ponude izravno povezane s temom odnosa čovjeka i prirode, prije svega zbog odnosa, tj. asocijacija koje kod većine ljudi izazivaju zmije

Budući da "duh prostora ne čine samo ljepote pejzaža i povijesne znamenitosti, već i karakter ljudi, običaji, način života, način ishrane, vizualna očuvanost ambijenta” (Baćac 2006:39), vrlo bitan segment život stanovnika nekog područja očituje se i kroz prizmu godišnjih običaja.

Kako je već navedeno, na istraživanim mikrolokalitetima Islama Latinskog, Islama Grčkog, Podgradini i Kašiću, zbog različite etničke i konfesionalne pripadnosti postoji bogatstvo običaja i razlika u njihovu obilježavanju. Na primjer, već se Sisvete kod hrvatskog stanovnišstva (u dijelu Grgurica) smatraju početkom božićnih običaja, dok je to Zadušnica kod srpskog stanovnišstva (u Kašiću). Božić i Uskrs svakako su dva najvažnija datuma iz ciklusa godišnjih običaja. Na Badnjak se odlazilo u šumu sjeći badnjak (drvo), njegovo unošenje u kuću odvijalo se prema strogo propisanim postupcima. Nakon što ga se stavilo na ognjište, polijevalo ga se vinom, posipavalo žitom i pri tom se izgovarala molitva (usp. Galić, Černelić 2010:255-300). Ovakvog badnjaka u suvremenom kontekstu više nema, no njegova prezentacija u obliku organiziranog sudjelovanja u običajima oko njega bila bi zanimljivo iskustvo, posebice ako je vezana uz ostale tradicijske elemente na Badnjak i Božić kao što su inventar stola (svijeća, tzv. Adonisovi vrtići, ukrašen kruh), zatim ukrašavanje kuće (slamom, zelenilom), specifična hrana. Bogatstvo božićnog ciklusa običaja posebno je izraženo kroz duhovne i društvene elemente: pjesme, plesanje kola ispred crkava, blagoslov kuća, odlazak u čestitanje, demonstracija vjerovanja i predviđanja iduće gospodarske godine, sreće u ljubavi i sl. Jasno je da bi svi ovi običaji, iako danas samo djelomično prakticirani, bili važna tema istraživanja ekomuzeja s obzirom na svaki pojedini element običaja i moguće varijacije prema konfesionalnoj pripadnosti stanovništva. 
Poklade - maškare - još su jedan sadržajno atraktivan običaj. Drugi veliki ciklus običaja vezan je uz Uskrs (usp. Galić, Černelić 2010:276-292). Povodom njega mogle bi se napraviti raznolike radionice, primjerice bojenje jaja s korijenom broća (biljka, korov) za crvenu boju, zatim kapulom (crvenim lukom), preslikavanje listova biljaka. Djeca bi mogla igrati razne igre s ukrašenim uskrsnim jajima: npr. tucanje jajima, gađanje jaja kovanicama. Organiziranje tečajeva pripreme specifične hrane vezane uz Uskrs ili boravak u nekom seoskom domaćinstvu zajedno s ukućanima, moguće su dodatne ideje. Ostali običaji vrijedni pažnje jesu blagoslov torova i polja na spomendan Svetoga Jurja (23. travnja). Na spomendan Sv. Ivana (24. lipnja) u Islamu Latinskom i Grguricama pravili su se veliki kresovi te se preskakalo preko vatre. Sudjelovanje u pravljenju krijesa i kasnije $s$ mještanima preskakanje preko njega, odnosno sudjelovanje u natjecanju ili, za one manje ambiciozne, obilazak kresova i promatranje, čini nam se da bi bili zanimljivi kako lokalnom stanovništvu, tako i gostima. Paljenje ovih obrednih vatri često je popraćeno karakterističnim pjesmama i plesovima (usp. Babić, Rajković Iveta 2009:323).

Prehrana istraživanih lokaliteta spoj je mediteranske i kontinentalne kuhinje. Osim ribe i morskih plodova zastupljena je domaća proizvodnja raznolikih prehrambenih artikala. Proizvodi koji su se pravili od mlijeka (kravljega u svim lokalitetima te ovčjeg i kozjeg u Posedarju) jesu sljedeći: sir izrađen s domaćim sirištem, varenika (kiselo mlijeko), skorup, skuta (kajmak), maslac, basa (vrsta sira u Kašiću). Tipične mesne prerađevine jesu: pršut, slanina, mast, čvarci, kobasice divenice ili dalmatinski kulen (sadrži kukuruzno brašno, krv i salo), kulen crni ili crne divenice (kulenice). Kruh se najčešće pekao pod pekom, a proizvodio se od pšeničnog, ječmenog, kukuruznog, raženog brašna, od prosa, od šilja i pira, kuruzovnica (suvrstica kruha - u njoj nema kvasa, peče se pod pekom, jede se vruća, topla, bude slatka). Zanimljiva je i izrada domaćeg kvasa, kave od ječma koji se peče u izvrnutoj peki ili brustulinu (posuda).

Tu nadalje pripada i pripremanje rajčice, repe, cikle, paprike, krastavaca za zimnicu na tradicijski način bez konzervansa, pečenje pekmeza i pravljenje domaćih sokova od trešnje, višnje maraške, jabuke, breskve, smokve, kruške, marelice te branje samoniklog bilja i plodova: gloginje, kupine, šparoge, koromač, divlja mrkva, divlji radič, kostriš te razne vrste gljiva. Peče se i rakija komovica od dropa. Lokalno stanovništvo aromatizira rakije stavljajući u njih kupine, višnje, koromač, ružmarin, origano, dunje, trešnje, šipak, pelin. Naši kazivači kazali su da izrađuju likere od kupina, liker od maraske, pelinkovac te orahovac. Lokalni kolači su smokvenjaci, prisnac ili presnac (pečen pod pekom), uštipci, fritule, kroštule, blagoslovnica (pinca, slatki kruh), friškača (suvrstica kruha nekisanog) (usp. Baćac 2010:301-334).

Ovdje su iznesene samo neke karakteristike lokalne prehrane. Budući ekomuzej svojim bi kontinuiranim istraživanjima i utjecajem aktivno podupirao održavanje tradicije vezane uz bogatu kulturu prehrane na ovom području te je po potrebi obnovio. Samorazumljivo je da ekomuzej to čini i u svim drugim područjima, no zbog popularnosti i brze isplativosti ovog oblika pretvorenog u turističku ponudu ekomuzej bi ovdje imao izuzetno važnu ulogu korektivnog mehanizma, neprekidno i uporno zagovarajući izvorne vrijednosti i argumentirajući protiv mogućih trivijalnosti i posvjetovljenja (usp. Babić, Rajković Iveta 2009:324).

Samo jedan, iako izuzetno važan, argument u tom pravcu u proizvodnji namirnica je inzistiranje na zastupljenosti što više autohtonih sorata od kojih bi se trebala proizvoditi organska hrana, koja bi se naravno nudila u gastronomskim objektima, domaćinstvima ili u obliku suvenirske ponude. Radionice u kojima bi bilo moguće sudjelovati u proizvodnji 
ili naučiti proizvoditi takvu hranu (pekmeze, kompote, sokove, čajeve) jedna su od najlogičnijih aktivnosti za koje bi sigurno postojao velik interes. Na ovaj način bi došlo i do poticanja otvaranja obiteljskih poljoprivrednih gospodarstava - OPG-ova, samozapošljavanja lokalnog stanovništva i velikog obogaćivanja turističke ponude šireg područja (ibid.).

Čajevima i uvarcima mogu se ublažavati simptomi i liječiti bolesti i smetnje probavnog trakta, dišnog sustava, kože, razni upalni procesi. U tu svrhu lokalno stanovništvo najčešće je koristilo pelin, lipu, nanu (metvicu), kamilicu, sljez, orah, šipak, koprivu, kadulju, rutu, ivu, gospinu travu, komorač te plodove šipka, štavljaka $i$ štrkalja (štrkljena) i bazge. Pojedine ljekovite trave lokalno stanovništvo i danas odlazi brati na padine južnog Velebita (usp. Galović 2010:335-366). Iz tema o narodnoj medicini zanimljiva bi bila prezentacija i priče o samoukim namjestačima kostiju, babicama (primaljama) te vjerovanjima o zdravlju i bolestima. U tragovima su zabilježena i vjerovanja u nadnaravna bića i pojave, primjerice urokljivog oka, mòre, vještice i/ili vračare te pojedini podaci o vampirima, vukodlacima i vilama (isto). Ove priče, njihova stručna interpretacija, svojevrsni su potencijal i moguća atrakcija.

Svi ovi izneseni podaci sumirani su rezultati do sada obavljenih, dvotjednih, istraživanja. Za kompletnu sliku u nastavku etnoloških terenskih istraživanja trebalo bi nužno obuhvatiti i teme iz rukotvorstva (tekstilnoga, iz lončarstva, kožarstva), obrte (kovačija, obrada drveta i tesarstvo), teme iz tradicijskog gospodarstva (ribarstvo, vinogradarstvo, stočarstvo, pčelarstvo) te teme iz životnih običaja (svadbene običaje, pogrebne običaje i sl.). Nadalje, prostor Ravnih kotara neiscrpan je za istraživanje kulture pamćenja i društvenog sjećanja. Zbog svoje zanimljive prošlosti mnoge teme iz tradicijske i suvremene kulture mogle bi se istraživati i kroz prizmu pograničnih kultura (usp. Černelić, Rajković Iveta 2010: 20-22). Tek nakon njih moglo bi se smatrati da je nužna istraživačka osnova, odnosno doprinos etnologije/kulturne antropologije, kao preduvjet formiranja ekomuzeja, postignut. Nije naodmet još jednom podsjetiti da ekomuzej, za razliku od nekih drugih formi, uvijek teži sveobuhvatnosti baštine na nekom području pri čemu je doprinos etnologije izuzetno važan (često i esencijalan), ali nikako ne i konačan. Sveobuhvatnost znači multidisciplinarnost ili, točnije interdisciplinarnost, svih područja znanosti kako bi se dobila kompleksna i kompletna slika istraživanog područja, koja zatim pod stručnim vodstvom i uz obvezatnu suradnju sa zajednicom može biti pretvorena u kvalitetnu i učinkovitu instituciju, generator razvoja.

Da bi uspio u svojoj ideji, ekomuzej mora biti oslonjen na zajednicu u kojoj djeluje jer je ona njegova osnova. Ona zato uvijek, i obvezatno, sudjeluje u njegovu planiranju, radu i upravljanju. Važno je naglasiti da ekomuzej izrasta kao odgovor na potrebe i želje ljudi koji žive i rade u području i on ih aktivno uključuje u sve svoje faze razvoja, dok se planira i stvara, i kasnije, kada je otvoren i djeluje, odnosno funkcionira (usp. Varine-Bohan 1993).

Za ekomuzeje je sve što je dio, ili bi moglo biti dio, identiteta zajednice relevantno, pri čemu važnost tih dijelova određuju ljudi koji žive u prostoru u kojem ekomuzej djeluje. Upravo te i takve elemente on uzima i koristi se njima u svom svakodnevnom radu. Ekomuzej štiti tako da stvarima i pojavama daje smisao koji su imali nekada, ili još uvijek imaju, i time ih održava aktivnima. Time one (po)ostaju dio svakodnevnog života zajednice. Ekomuzej nema publiku u klasičnom smislu, njegova publika, tj. korisnik, je cijela zajednica u kojoj se nalazi te njihovi gosti, koji nikada nisu cilj već dobrodošli sudionici procesa (usp. Babić 2010, Babić, Rajković Iveta 2009). 
Pojedini, u ovom izlaganju navedeni, elementi pokazatelj su dijela vrijednosti koje obrađeno područje posjeduje i koji još uvijek čekaju da na kvalitetan način budu (re)interpretirani - kako samoj zajednici koja ih posjeduje, tako, uz pomoć nje, i njihovim potencijalnim gostima. Progresivan razvoj kulturnog turizma u svijetu, posebice ruralnog i baštinskog, svjedoči da bi interes za ovo drugo sigurno postojao. Kvalitetan odgovor koji bi realizirao potencijale s obzirom na oba postavljena izazova, ne narušavajući pritom ravnotežu odnosa čovjeka i baštine, sigurno bi trebao biti ekomuzej, čiji bi centar svakako trebalo smjestiti u vrijednom spomeniku kulture ovoga područja - prostoru Kule Stojana Jankovića u Islamu Grčkom.

Da sumiram, saznanja prikazana u ovom radu mogu se koristiti za revitalizaciju područja i to na više načina: obogaćivanjem kulturno-turističke ponude, kroz turizam baštine i kreativni turizam (primjerice kroz maslinarstvo, narodnu medicinu); interdisciplinarnim radionicama na kojima bi se izlagalo rezultate istraživanja i davalo smjernice za revitalizaciju pojedinih grana tradicijske baštine, kao primjerice tradicijskoga graditeljstva i kulture stanovanja, sa svrhom obnove i revitalizacija ruralnih cjelina; tradicijskoga iskorištavanja energije i prirodnih resursa i u svakodnevnom životu (povezivanje s alternativnim izvorima energije), kroz istraživanje tradicijskog gospodarstva; saznanja kako živi lokalno stanovništvo (kroz mogućnosti boravka na seoskom domaćinstvu ili gospodarstvu) kroz tradicijsku prehranu itd. Nadalje, saznanja se mogu koristiti i u radionicama u kojima bi se nastojalo senzibilizirati lokalnu zajednicu za baštinu, za osmišljavanje izvornih ekoproizvoda i suvenira. Rezultati pokazuju da svojom bogatom povijesnom i kulturnom baštinom ovo područje može privući posjetitelje, turiste, znanstvenike i studente te ostvariti bolju gospodarsku svakodnevicu.

Istaknula bih da su se obitelji Janković i Desnica u prošlosti i sami bavili tradicijskom kulturom, ne samo kao sudionici, često kroz komunikaciju i dijalog s lokalnim stanovništvom (primjerice, na prostoru između Kule i obiteljske crkve sv. Jurja nalazi se gumno na kojem je i lokalno stanovništvo vršilo žito, u Kuli su se cijedile masline odnosno proizvodilo maslinovo ulje i sl.), stanovnici Kule bili su i "tumači” tradicijske kulture u širokom rasponu od konstrukcije etnografskih zbirki, skupljanja pučkih umotvorina itd. i ljudi koji su ih literarno transponirali, ponajviše Vladan Desnica.

\section{$\cos$}

\section{Literatura}

Babić, Darko i Marijeta Rajković Iveta. 2009. "Prilog za razvoj ekomuzeja u Ravnim kotarima". Studia ethnologica Croatica 21:307-329.

BAĆAC, Robert. 2006. "Agroturizam - tradicijske vrijednosti u funkciji turizma”. U Etnologija i kulturnu turizam, ur. Tihana Petrović Leš i Tomislav Pletenac. Zagreb, 36-42.

BAĆAC, Valentina. 2010. “Tradicijska prehrana”. U Zapisi iz gornjih Ravnih kotara, etnološki, povijesni i muzeološki prilozi o Islamu Latinskom, Islamu Grčkom, Kašiću i Podgradini, ur. Milana Cernelić, Marijeta Rajković Iveta. Zagreb: Centar za komparativnohistorijske i interkulturne studije Filozofskog fakulteta - FF-press, 301-334.

BRTAN, Joso. 2002. Župa Islam Latinski. Zadar, 7-12.

Černelić, Milana i Marijeta Rajković Iveta. 2010. "Uvod". U Zapisi iz gornjih Ravnih kotara, etnološki, povijesni i muzeološki prilozi o Islamu Latinskom, Islamu Grčkom, Kašiću i Podgradini. 
ur. Milana Černelić, Marijeta Rajković Iveta. Zagreb: Centar za komparativnohistorijske i interkulturne studije Filozofskog fakulteta - FF-press, Zagreb, 20-22.

Galić, Ivan i Milana ČErnelić. 2010. "Pregled godišnjih običaja”. U Zapisi iz gornjih Ravnih kotara, etnološki, povijesni i muzeološki prilozi o Islamu Latinskom, Islamu Grčkom, Kašiću i Podgradini. ur. Milana Cernelić, Marijeta Rajković Iveta. Zagreb: Centar za komparativnohistorijske i interkulturne studije Filozofskog fakulteta - FF-press, 255-300.

GALOvić, Sanja. 2010. “Tradicijska medicina, vjerovanja u nadnaravna bića, porođaj i higijena”. U Zapisi iz gornjih Ravnih kotara, etnološki, povijesni i muzeološki prilozi o Islamu Latinskom, Islamu Grčkom, Kašiću i Podgradini. ur. Milana Cernelić, Marijeta Rajković Iveta. Zagreb: Centar za komparativnohistorijske i interkulturne studije Filozofskog fakulteta - FF-press, 335-366.

Кокотоvıć, Mura. 2010. "Maslinarstvo”. U Zapisi iz gornjih Ravnih kotara, etnološki, povijesni i muzeološki prilozi o Islamu Latinskom, Islamu Grčkom, Kašiću i Podgradini. ur. Milana Cernelić, Marijeta Rajković Iveta. Zagreb: Centar za komparativnohistorijske i interkulturne studije Filozofskog fakulteta - FF-press, 177-210.

Kокотоvıć, Mura. 2010. “Tradicija lova i lovnog turizma”. U Zapisi iz gornjih Ravnih kotara, etnološki, povijesni i muzeološki prilozi o Islamu Latinskom, Islamu Grčkom, Kašiću i Podgradini. ur. Milana Černelić, Marijeta Rajković Iveta. Zagreb: Centar za komparativnohistorijske i interkulturne studije Filozofskog fakulteta - FF-press, 211-222.

LoNČAR, Sanja. 2010. "Prilozi poznavanju ruralnog graditeljstva i kulture stanovanja”. U Zapisi iz gornjih Ravnih kotara, etnološki, povijesni i muzeološki prilozi o Islamu Latinskom, Islamu Grčkom, Kašiću i Podgradini. ur. Milana Černelić, Marijeta Rajković Iveta. Zagreb: Centar za komparativnohistorijske i interkulturne studije Filozofskog fakulteta - FF-press, 73-176.

Nikolić, Tamara. 2010. "Poljoprivreda, opskrba vodom i navodnavanje”. U Zapisi iz gornjih Ravnih kotara, etnološki, povijesni i muzeološki prilozi o Islamu Latinskom, Islamu Grčkom, Kašiću i Podgradini. ur. Milana Cernelić, Marijeta Rajković Iveta. Zagreb: Centar za komparativnohistorijske i interkulturne studije Filozofskog fakulteta - FF-press, 223-254.

Rihtman-Auguštin, Dunja i Aleksandra Muraj. 1998. Prvih pedeset godina etnološke misli u Institutu. Narodna umjetnost 35/2:103-124.

Varine-Bohan, Huges de. 1993. “Tommorrow's community museum”, http://assembly.coe.int/ Museum/ForumEuroMusee/Conferences/tomorrow.htm (pristup 20. 5. 2014.). 